\title{
THE EFFECT OF RETENTION FACTORS ON ORGANISATIONAL COMMITMENT: AN INVESTIGATION OF HIGH TECHNOLOGY EMPLOYEES
}

\author{
ANDREAS DÖCKEL \\ andreas.dockel@jhb.za.sytes.com \\ JOHAN S BASSON \\ Johan.Basson@up.ac.za \\ Department Human Resource Management \\ University of Pretoria \\ MELINDE COETZEE \\ Coetzm1@unisa.ac.za \\ Department Industrial \& Organisational Psychology \\ University of South Africa
}

\begin{abstract}
The objective of the present study was to investigate specific retention factors that induced the organisational commitment of high technology employees. A sample of 94 professional technicians from a South African owned telecommunications company based in the Gauteng province participated. The Organisational Commitment Scale and a retention factor measurement scale were administered. The most relevant explanatory factors were compensation, job characteristics, supervisor support, and work/life policies, which appeared to have a statistically significant influence on the development of organisational commitment in high technology employees. The implications of the findings are discussed.
\end{abstract}

Key words

Retention factors, organisational commitment, high technology employees

There is a revolutionary change in the world of work that impacts on the individual, work and society. The future of work suggests flexibility, boundaryless communities and change in work as we know it today (Baruch, 2004; Weiss, 2001). As the world of work changes from a worker-intensive, industrial society to an automated information society, the workforce increasingly becomes more educated with higher professionalism and a decrease in organisational loyalty (Baugh \& Roberts, 1994; Furnham, 2000). In addition, high technology industries operate in volatile markets and experience accelerating growth and rates of change. High technology employees are educated, have a strong preference for independence and hold a large portion of the organisation's intellectual capital (McNee, Morello, Zidar \& Smith, 1998; Murphy, 2000). Employers struggle to retain their valuable high technology employees due to a general shortage of experienced candidates and aggressive recruitment tactics by others in the high technology arena (De Young, 2000; Evans, Gonzalez, Popiel \& Walker, 2000; Storey, 1992).

The high technology worker identifies with a high technology culture separate from the organisation in which he or she works (Rogers, 2001). This focus leads to a loyalty clash. High technology workers want to work on projects that enhance their careers, knowledge assets and future earning power, while the organisation generally wants current knowledge applied to developing value-added products. This clash is a common source of problems for firms wanting to retain high technology workers (Von Glinow \& Mohrman, 1990).

The retention of technical staff and their organisational commitment appear to be of strategic importance to high technology employers because of the potential financial returns on them in the long term (Chambers, 1998; Huselid, 1995; Turbin \& Rosse, 1990). Loyal, engaged employees tend to generate high performance business outcomes as measured by increased sales, improved productivity, profitability and enhanced employee retention (Rogers, 2001; Tsui, Pearce, Porter \& Hite, 1995). Commitment strategies shape desired employee behaviours and attitudes by forging psychological links between the organisation and employee goals. Thus, the focus is on developing committed employees who can be trusted to use their discretion to carry out job tasks in ways that are consistent with organisational goals (Eisenhardt, 1985; Storm \& Roodt, 2002).
This research sets out to investigate specific retention factors that induce organisational commitment and can thus increase the retention of high technology employees.

\section{Organisational commitment}

The concept of organisational commitment has attracted considerable interest in an attempt to understand and clarify the intensity and stability of an employee's dedication to the organisation (Mester, Visser, Roodt \& Kellerman, 2003). Researchers have distinguished between three approaches to study commitment, namely from an attitudinal, behavioural and a motivational perspective. In the context of this study, organisational commitment is regarded as an attitude as it relates to individuals' mindsets about the organisation (Allen \& Meyer, 1990). Meyer and Allen's (1991) three component model of organisational commitment is therefore of relevance to this research.

According to Meyer and Allen (1997) the concept of organisational commitment is a construct distinguishable from other familiar concepts such as job satisfaction, job involvement, career salience, occupational commitment, turnover intentions, work group attachment and Protestant work ethic (Cohen, 1993; Mathieu \& Farr, 1991; Meyer, Allen \& Smith, 1993; Morrow \& McElroy, 1986; Mueller, Wallace \& Price, 1992). Allen and Meyer (1990) describe commitment as a psychological state that binds the individual to the organisation. Meyer and Herscovitch (2001) suggest that the binding force of commitment is experienced as a mindset (i.e. a frame of mind or psychological state that compels an individual toward a course of action). The mindsets reflect three distinguishable themes which Meyer and Allen (1991) label as affective commitment, continuance commitment, and normative commitment. These three distinguishable components of organisational commitment reflect a difference between a preference to stay with the present organisation arising out of a sense of emotional attachment (affective commitment), compared to one rooted in a sense of economic necessity or the perceived cost of leaving (continuance commitment) or of moral obligation (normative commitment).

Organisational commitment develops during employment in the organisation. Meyer and Herscovitch (2001) developed some propositions that encompass the development of the different 
mindsets: The mindset of desire (affective commitment) develops when an individual becomes involved in, recognises the value-relevance of, and/or derives his or her identity from, association with an entity or pursuit of a course of action. The mindset of perceived cost (continuance commitment) develops when an individual recognises that he or she stands to lose investments, and/or perceives that there are no alternatives other than to pursue a course of action relevant to a particular target. The mindset of obligation (normative commitment) develops as a result of the internalisation of norms through socialisation, the receipt of benefits that induces a need to reciprocate, and/or acceptance of the terms of a psychological contract.

Employees who have strong confidence in their abilities and achievements have higher affective commitment. A possible explanation for the observed relation between the two variables is that competent people are able to choose higher-quality organisations, which in turn inspires affective commitment (Mathieu \& Zajac, 1990). Affective commitment has shown a positive correlation with job scope, a composite of three variables, that is, job challenge, degree of autonomy and variety of skills used. Affective commitment to the organisation is stronger among employees whose leaders allow them to participate in decision making (Rhodes \& Steers, 1981) and those who treat them with consideration (DeCotiis \& Summer, 1987).

Continuance commitment originates from the "side bets" tradition (Becker, 1960) and refers to the employee's sacrifices (e.g. losing seniority or pension benefits) associated with terminating employment, thus the employee becomes aware of the costs that are associated with leaving the organisation. Employees who have strong continuance commitment to an organisation stay with the organisation because they believe they have to do so.

Meyer and Allen (1997) show continuance commitment to be related to employees' perceptions about the transferability of their skills to other organisations. Employees who thought their training investments were less easily transferable elsewhere expressed stronger continuance commitment to their current organisation. Employees whose primary link to the organisation is based on strong continuance commitment stay with the organisation not for reasons of emotional attachment, but because of a recognition that the costs associated with doing otherwise are simply too high. All things being equal, there is no reason to expect that such employees will have a particularly strong desire to contribute to the organisation (Meyer \& Allen, 1997).

According to Wiener (1982), normative commitment to the organisation develops on the basis of a collection of pressures that individuals feel during their early socialisation (from family and culture) and during their socialisation as newcomers to the organisation. Meyer and Allen (1997) suggest that normative commitment develops on the basis of a particular kind of investment that the organisation makes in the employee, specifically investments that seem difficult for employees to reciprocate (Meyer \& Allen, 1991; Scholl, 1981).

Strong normative commitment involves being tied to the organisation by feelings of obligation and duty. Meyer and Allen (1991) argue that, generally, such feelings would motivate individuals to behave appropriately and do what is right for the organisation. It is expected that normative commitment to the organisation will be positively related to such work behaviours as job performance, work attendance and organisational citizenship.

Sethi, Meinert, King and Sethi (1996) suggest that organisations need to re-examine policies that lead to building commitment. Commonly employed strategies in a high technology environment, such as nonvested pension plans, participation in stock options and the development of organisation-specific skills may in fact be working against the organisation. Although these steps make it difficult for employees to leave, they may not encourage them to stay. Some employees may find themselves in a position where they want to quit, but may not be able to afford to do so. Some may be motivated to do just enough to maintain their jobs. In these cases, commitment fostering steps may actually be counterproductive. Affective commitment may be harder to foster but is strongly related to the results that organisations value - the employee's desire to contribute to the organisation's effectiveness.

In previous studies, age and organisational tenure were controlled and these are thus a concern in this study as well (Allen \& Meyer, 1993; Luthans, McCaul \& Dodd, 1985; Meyer \& Allen, 1984; Miner, 1988). Meta-analytic evidence suggests that age and organisational commitment are significantly, albeit weakly, related (Mathieu \& Zajac, 1990). This relationship exists even when variables that are often confounded with age (organisational and position tenure) are controlled (Allen \& Meyer, 1993). Meyer and Allen (1984) have suggested that older workers become more attitudinally committed to an organisation for a variety of reasons, including greater satisfaction with their jobs, having received better positions, and having "cognitively justified" their continuance in an organisation. Organisational tenure has often been used as a surrogate for side bets (Meyer \& Allen, 1984). The general assumption is that as individuals accumulate more years with a company, they are likely to acquire greater investments, for example pension plans, and develop greater continuance commitment. Organisational tenure has consistently been found to be positively associated with organisational commitment (Paré, Temblay \& Lalonde, 2001).

\section{Retention factors}

Cascio (2003) describes retention as initiatives taken by management to keep employees from leaving the organisation, such as rewarding employees for performing their jobs effectively; ensuring harmonious working relations between employees and managers; and maintaining a safe, healthy work environment. Literature surveys conducted by McNee et al. (1998) and Döckel (2003) identified the following six critical factors that need to be considered in the retention of high technology employees: compensation (base salary); job characteristics (skill variety and job autonomy); training and development opportunities; supervisor support; career opportunities and work/life policies.

Compensation: Money is still the primary incentive used to lure high technology professionals. According to Higginbotham (1997), high salaries are not essential, but "good" and "fair" salaries showed a strong correlation with intention to stay, indicating that as long as the compensation is competitive, financial rewards are not the primary factor in retention. Kochanski and Ledford (2001) support this statement, which indicates that the actual level of pay is less important than feelings about pay raises and the process used to administer them. Employees want to understand how the pay system works, and want to know how they can earn pay increases. Once the pay level has been reached the intangibles such as career, supervisor support, work and family balance become important (Tomlinson, 2002).

High technology employees are very receptive to stock options, and are likely to base retention decisions on such options, particularly in organisations with high growth potential (Higginbotham, 1997; Kochanski \& Ledford, 2001). It appears that salary alone provides insufficient motivation for many high technology employees, but monetary compensation in the form of bonuses and profit sharing provides a measure of performance feedback that is often more effective with high technology professionals, for example engineers (Balkin \& Gomez-Meija, 1984). Elaborate benefit packages are becoming increasingly common in high technology firms, making them 
more of a compensation issue and less of an incentive to stay with the current organisation. These are the indirect financial rewards employees receive for their labour. They consist of time off, benefit processes and benefit levels (Farris, 2000).

High technology employees do not work normal office hours, but work at a pace that invites burnout. Time off, according to Kochanski and Ledford (2001), is more important than any other indirect benefit in predicting retention. High technology employees seem to care less about how benefits are administered than about the value of benefits. In addition, DeYoung (2000) supports the notion that retention benefits are of an environmental and personal nature, for instance, luxury automobiles for anyone who has surpassed their goals, pets in the office because high technology workers spend a lot of time away from home, playrooms and quiet rooms to improve team work and reduce stress, and on-site gyms for employees to work out their stress.

Compensation offers an opportunity for security, autonomy, recognition and an improved self worth (Hoyt \& Gerdloff, 1999). These increased feelings of self worth and importance should lead to affective commitment. Mathieu and Zajac (1990) indicate a positive correlation between salary and commitment. Igbaria and Greenhaus (1992) found salary to be positively related to organisational commitment and negatively related to turnover. Perceptions of fairness in compensation have also been shown to be positively linked to affective organisational commitment (Schaubroeck, May \& Brown, 1994).

Job characteristics: High technology employees want to do interesting work that challenges them and uses their skills and talents. Repetitive, narrow work experience with little individual discretion repels high technology employees (Kochanski \& Ledford, 2001). Research has shown that the design of high technology professionals' work content influences the stability of the technical workforce (Amabile, Conti, Coon, Lazenby \& Herron, 1996). Furthermore when high technology professionals view their tasks as challenging with opportunities for learning and information exchange they are also less likely to leave. According to Amabile et al. (1996) and Glynn (1996), high technology professionals, for example engineers, appeared to be more involved, more satisfied with their jobs, and more committed to the organisation than nontechnical employees.

Job characteristics, such as variety and autonomy, are wellestablished determinants of organisational commitment (Pretorius \& Roodt, 2004). According to Dubie (2000), loyal, high technology employees enjoy the autonomy they receive in their current jobs. According to Marsh and Mannari (1977) the higher the level of autonomy that the individual possesses, the more negatively it is correlated with turnover.

According to McEachern (2001), high technology employees will leave the organisation if their skills are underutilised. Mathieu and Zajac (1990) found a positive correlation between skill variety and organisational commitment. One way that individuals may develop a sense of competency is by working in a job with high skill variety (Hackman \& Oldham, 1975; 1976). Skill variety relates to feelings of belonging and a sense of attachment to the organisation (Meyer \& Allen, 1991). Skill variety is thus more related to affective commitment than continuance commitment because of the increased feelings of belonging.

Training and development opportunities: According to Cataldo, Assen and D'Alessandro (2000), employees with key information technology skills have become increasingly hard to find. Many companies have realised that proactive strategies are required for building and maintaining a high technology company's knowledge reservoir. Training is therefore essential for the survival of any information technology worker, and is the only way they can stay employable over the span of their careers.
Tomlinson (2002) suggests it is critical that organisations keep the leading edge by having their employees well trained in the latest technologies. Employees stay at companies that promote career opportunities through learning, and the ability to apply their newly learned skills (Cataldo et al., 2000; Jiang \& Klein, 2000). The primary mechanism by which training is predicted to increase organisational commitment is through increased self worth and importance.

According to Chang (1999), company-provided training might affect the psychological states of employees. When employees believe that the company is doing a good job of providing proper training, they feel that the company is concerned with improving their skill and ability, making them attached to their company. If training is perceived as providing organisationspecific skills that contribute to status or economic advantage within the company, but will not transfer to jobs outside the organisation, a stronger continuance commitment will develop. Extensive training should have little effect on continuance commitment, unless the training involves organisation-specific skills. Paré et al. (2001) found training to be negatively related to continuance commitment.

Employees who are aware of the expense of training, or appreciate the skills they have acquired, might develop a sense of obligation (normative commitment). This will hold them in the organisation at least long enough to "reciprocate". The employees might develop a moral obligation to give the organisation its money's worth (normative commitment), particularly if the company funds the training (McElroy, 2001).

Supervisor support: For the purpose of this study, supervisor support refers to supervisory behaviours that sustain the high technology employee's innovation, such as reward and recognition. Most valuable high technology employees are staff with critical innovation skills, the people with knowledge of core products or services. Most of the high technology employee's work is tacit and often ambiguous and difficult to measure. According to Kochanski and Ledford (2001), high technology employees value the feedback from their coworkers and supervisors. Providing sufficient performance feedback to employees helps bolster positive attitudes toward the organisation and helps prevent early intentions to leave the organisation.

According to Eisenberger, Fasalo and Davis-LaMastro (1990), affective commitment may be enhanced under conditions of high feedback. As individuals are provided with praise and feedback, stronger feelings of loyalty to the organisation may develop. Paré et al. (2001) indicate that recognition from the supervisor has been found to be related to affective commitment but not to continuance commitment. The reason for this might be that high technology employees explore new solutions and get feedback and recognition from supervisors, which increase their feelings of self worth, and not their obligation to stay at the company.

Career opportunities: Labour market trends in the information technology field have continued to present increased career opportunities for high technology employees and hiring and retention challenges for the organisations that employ these workers. Kochanski and Ledford's (2001) survey shows that career opportunities yield more significant predictors of retention than any other type of reward, followed by training opportunities and an employee's relationship with his or her supervisor.

According to Baruch (2004), perceptions of the organisation's adherence to career-orientated practices, including internal promotions, training and development and employment security are positively related to commitment. Psychological commitment is higher among employees who believe they are being treated as resources to be developed rather than 
commodities to buy and sell. Investing in employees sends the message that companies value them.

Work/life policies: Work/life policies include flexible work scheduling (e.g. part-time work, job-sharing, variable starting and quitting times), family leave policies allowing periods away from work for employees to take care of family matters, and childcare assistance (e.g. referral service, on-site or offsite care centres) (Burke \& Cooper, 2002). McCrory (1999) indicates that the majority of high technology workers value work/life initiatives as very meaningful. Loyal, high technology employees (those who cannot envision changing jobs in the foreseeable future) are more concerned with leave (vacation, holidays etc), flexible work schedules, family friendliness and a proximity to their home, than job seeking employees who are actively looking for a new position (Dubie, 2000).

Grover and Crooker (1995) empirically tested the effects of work and family benefits on organisational commitment. These benefits include parental leave, flexible schedules, childcare assistance and childcare information. Employees who had access to work/life policies showed significantly greater organisational commitment and expressed significantly lower intention to quit their jobs. Work/life policies were reported by Paré et al. (2001) to be minimally related to affective commitment, and negatively to continuance commitment. This might be the result of the individual being forced to stay at the organisation to increase investments rather than to have less work/life conflict. Owing to the lock-in effect, employees are forced to focus more on work than their families. This may not make for a committed employee.

In view of the foregoing, it was expected that the identified retention factors are positively associated with the three components of Meyer and Allen's (1991) organisational commitment model, that is, it could be expected that each form of commitment would be negatively correlated with employees' intention to leave the organisation and with voluntary turnover behaviour.

The purpose of the study was therefore to establish whether specific retention factors can induce organisational commitment. More specifically, the goal was to investigate whether:

- there was a significant correlation between the identified retention factors and individuals' organisational commitment

- retention factors had a substantial effect on individuals' organisational commitment

\section{RESEARCH DESIGN}

\section{Research approach}

A survey design was used to achieve the research objectives (Shaughnessy \& Zechmeister, 1997).

\section{Participants}

A purposive sample of 94 nonrandomly selected professional technicians from a South African owned telecommunications company based in the Gauteng province was used in the present study. The majority of the participants were white males $(89.36 \%)$ with females representing only 10.64 percent of the total sample. In terms of age, 81.9 percent of the participants were between the ages of 20 and 34, and 10.1 percent between the ages 35 and 45 . Most of the participants $(63.83 \%)$ had a tertiary education, achieving a post school certificate or diploma at a technikon. The majority of the participants (91.49\%) indicated five or fewer years of organisational tenure with the company and a low percentage of absenteeism (42.55\%). A large proportion of the participants $(59.57 \%)$ also participated in an incentive scheme. Most of the participants (85.11\%) were involved in overtime at the organisation, working between 1 and 19 hours overtime per week.

\section{Measuring instruments}

Two measuring instruments, namely the Organisational Commitment Questionnaire (Meyer et al., 1993) and a retention factor measurement scale developed by Döckel (2003), were used in the present study. A biographical questionnaire was used to obtain personal details of the participants.

\section{Organisational Commitment Questionnaire (OCQ)}

Organisational commitment was measured using the threedimensional Meyer et al. (1993) instrument that was originally developed by Allen \& Meyer (1990). The affective, continuance and normative organisational commitment scales each comprise six items, a modification of the original questionnaire. Meyer et al. (1993) reported internal consistency reliability estimates (Cronbach's alphas) for affective commitment (0.82), continuance commitment (0.74) and normative commitment $(0.83)$. Responses were made on a 7 -point scale ( $1=$ strongly disagree and $7=$ strongly agree) and were averaged to yield composite commitment scores for each respondent.

\section{The Retention Factor Measurement Scale (RFMS)}

The questionnaire consisted of 35 items and was presented in the form of a five-point Likert scale ranging from strongly disagree (1) to strongly agree (5). The RFMS was developed by using items that originated from questionnaires that were designed to measure compensation, job characteristics, training and development opportunities, supervisor support, career opportunities and work/life policies (Döckel, 2003).

Compensation: Thirteen items regarding compensation factors pertaining to level, benefits, raises, structure/administration were selected from the Pay Satisfaction Questionnaire (Heneman \& Schwab, 1985). Results reported by Heneman and Schwab (1985) show high internal consistency reliabilities for the four scales.

Job characteristics: The Job Diagnostic Survey (Hackman \& Oldham, 1975; 1976) was used with two items comprising each dimension, namely skill variety and job autonomy. Fried and Farris's (1987) meta-analyses reported a Cronbach alpha coefficient in the range of 0.20 to 0.94 .

Training and development opportunities: Six items based on a scale developed by Rogg, Schmidt, Shull and Schmitt (2001) were selected and used in the RFMS. Rogg et al. (2001) reported a Cronbach alpha coefficient of 0.77 to 0.87 for training and development opportunities.

Supervisor support: Six items based on a scale developed by Ramus \& Steger (2000) were selected. A Cronbach alpha coefficient of 0.68 was reported for the scale.

Career opportunities: Four items based on Landau \& Hammer's (1986) measurement scale on perceived ease of movement and perceived organisational policy of filling vacancies from within were selected.

Work/life policies: Four items based on Paré et al.'s (2001) work/life policies scale were selected. A Cronbach alpha coefficient of 0.87 was reported for the scale.

A factor analysis on the RFMS conducted by Döckel (2003) confirmed the construct validity of the questionnaire.

\section{Procedure}

The questionnaires were sent to the participants via the company's internal mail system. A covering letter explaining the purpose of the study and the assurance that all information 
would be used for research purposes only accompanied each questionnaire. All questionnaires were answered anonymously and participation in the study was voluntary. Completed questionnaires were sent back to the researchers via the internal mail system.

\section{Statistical analysis}

The statistical analysis was carried out with the help of the SAS program (SAS Institute, 2000). The analyses of data involved three stages. Firstly, Cronbach alpha coefficients and inter-item correlations were used to assess the internal consistency of the measuring instruments (Clark \& Watson, 1995). A Cronbach alpha coefficient of greater than 0.75 is generally considered reliable (internally consistent) (Terre Blanche \& Durrheim, 1999). Secondly, Pearson productmoment correlation coefficients were used to determine the magnitude of the relationships between each of the variables. Finally, multiple linear regression was conducted to determine the separate and collective contributions of each of the specified independent variables (retention factors) to the variations of a dependent variable (organisational commitment). This is one of the most commonly used multivariate procedures in the social sciences, and is used to build models for explaining and predicting scores on the dependent variable from scores on a number of other independent variables (Terre Blanche \& Durrheim, 1999). A cut-off point of $\mathrm{p}<0,05$ was set for the interpretation of the statistical significance of the results.

\section{RESULTS}

Table 1 presents the results of the internal consistency of each scale as measured by Cronbach alpha coefficients. The internal consistency reliabilities for the total sample as measured by Cronbach alpha coefficients are moderately high, with the exception of somewhat lower reliabilities for continuance commitment and job characteristics. A desirable reliability coefficient would usually fall in the range of 0.8 to 0.9 (Tredoux \& Durrheim, 2002). However, in the case of individual testing reliabilities as low as 0.3 are quite acceptable when instruments are used to gather group data (Tredoux \& Durrheim, 2002). The internal consistency coefficients for the organisational commitment scales and the retention factors are generally regarded as acceptable.
TABLE 1

RELIABILTIES FOR THE OCQ AND RFMS

\begin{tabular}{lcc}
\hline Scale & $\begin{array}{c}\text { Cronbach alpha } \\
\text { Coefficient }\end{array}$ & Number of items \\
\hline OCS & 0,78 & 6 \\
Affective commitment & 0,61 & 5 \\
Continuance commitment & 0,76 & 6 \\
Normative commitment & & \\
RFMS & 0,90 & 13 \\
Compensation & 0,41 & 2 \\
Job characteristics & 0,83 & 6 \\
Training \& Development & 0,90 & 6 \\
Supervisor support & 0,76 & 4 \\
Career opportunities & 0,87 & 4 \\
Work/life policies & & \\
\hline
\end{tabular}

The correlation coefficient matrix is presented in Table 2, indicating that all the independent variables are strongly and significantly related to organisational commitment except for job characteristics, age and organisational tenure. The correlation coefficients vary between -0.409 and 0.85 . All the retention factors except job characteristics, age and organisational tenure had a strong and significant relation to affective commitment. Only the work/life policy factor shows a significant positive relation to continuance commitment. Job characteristics show a significant negative relation to continuance commitment. The other independent variables, namely compensation, training and development opportunities, supervisor support, career opportunities, age and organisational tenure were poorly and non-significantly related to continuance commitment.

All the retention factors except job characteristics, work/life policies, age and organisational tenure had a strong and significant relation to normative commitment. All the retention factors except job characteristics, age and organisational tenure had a strong and significant relation to organisational commitment as a total of all the different commitments. Age and organisational tenure had no correlation with any of the commitment components, and thus were excluded in the multiple linear regression model.

TABle 2

INTERCORRELATION MATRIX OF SCORES ON THE OCQ AND RFMS (N = 94)

\begin{tabular}{|c|c|c|c|c|c|c|c|c|c|c|c|c|c|c|}
\hline M & SD & $\mathrm{AC}$ & $\mathrm{CC}$ & $\mathrm{NC}$ & OC & COMP & JC & TD & SS & $\mathrm{CO}$ & WLP & AGE & OT & \\
\hline AC & 3,61 & 0,70 & 1,0 & & & & & & & & & & & \\
\hline $\mathrm{CC}$ & 3,07 & 0,70 & 0,12 & 1,0 & & & & & & & & & & \\
\hline $\mathrm{NC}$ & 3,33 & 0,72 & $0,65^{* *}$ & $0,12^{*}$ & 1,0 & & & & & & & & & \\
\hline OC & 3,34 & 0,53 & $0,79 * *$ & $0,60^{* *}$ & $0,85^{* *}$ & 1,0 & & & & & & & & \\
\hline COMP & 3,04 & 0,66 & $0,40^{* *}$ & 0,08 & $0,36^{* *}$ & $0,38^{* *}$ & 1,0 & & & & & & & \\
\hline JC & 4,19 & 0,60 & $-0,01$ & $-0,22^{*}$ & 0,03 & $-0,08$ & 0,01 & 1,0 & & & & & & \\
\hline $\mathrm{TD}$ & 3,24 & 0,76 & $0,36^{* *}$ & 0,10 & $0,36^{* *}$ & $0,37^{* *}$ & 0,47 * * & $0,22^{*}$ & 1,0 & & & & & \\
\hline SS & 3,45 & 0,89 & $0,47^{* *}$ & 0,04 & $0,29^{* *}$ & $0,36^{* *}$ & $0,26^{*}$ & $0,22^{*}$ & $0,39^{* *}$ & 1,0 & & & & \\
\hline $\mathrm{CO}$ & 3,02 & 0,79 & $0,45^{* *}$ & 0,03 & $0,29^{* *}$ & $0,34^{* *}$ & $0,27^{* *}$ & 0,11 & $0,59^{* *}$ & $0,52^{* *}$ & 1,0 & & & \\
\hline WLP & 3,05 & 0,96 & $0,35^{* *}$ & $0,21^{*}$ & 0,14 & 0,31 * * & 0,05 & $-0,10$ & 0,19 & $0,33^{* *}$ & 0,33 * * & 1,0 & & \\
\hline AGE & 29,99 & 5,86 & 0,05 & $-0,16$ & 0,05 & $-0,02$ & 0,19 & 0,09 & 0,02 & $-0,15$ & $-0,29^{* *}$ & 0,04 & 1,0 & \\
\hline OT & 2,86 & 2,04 & $-0,17$ & $-0,11$ & $-0,09$ & $-0,16$ & $-0,03$ & $-0,06$ & $-0,82$ & $-0,28^{* *}$ & $-0,41^{* *}$ & $-0,34^{* *}$ & $0,35^{* *}$ & 1,0 \\
\hline
\end{tabular}

** $\mathrm{p}=0,01 ;{ }^{*} \mathrm{p}=0,05$

$\mathrm{AC}=$ Affective commitment; $\mathrm{CC}=$ Continuance commitment $\mathrm{NC}=$ Normative commitment; $\mathrm{OC}=$ Organisational commitment; $\mathrm{COMP}=\mathrm{Compensation} ; \mathrm{JC}=\mathrm{Job}$ characteristics; $\mathrm{TD}=$ Training and development; SS = Supervisor support; $\mathrm{CO}=$ Career opportunities; $\mathrm{WLP}=$ Work/life policies; AGE = Age; OT = Organisational tenure 
Multiple linear regression was calculated on the three commitment components and on organisational commitment as an overall measure of commitment. The results are reported in Tables 3 to 6 . In Table 3 the results of the relation between the specified independent variables and affective commitment are presented. The overall model is significant at the 0.01 level. The retention factors explain 38 percent of the variance in affective commitment. Of the independent variables, compensation $(+)$, supervisor support $(+)$ and work/life policies $(+)$ are the only predictors statistically different from zero and had a significant and direct effect on affective commitment. The remaining independent variables, namely job characteristics (-), training and development opportunities (+) and career opportunities $(+)$ had no significant direct effect on affective commitment.

TABLE 3

MULTIPLE LINEAR REGRESSION ANALYSIS OF RFMS SCORES ON OCQ AFFECTIVE COMMITMENT $(\mathbf{N}=94)$

\begin{tabular}{lcccc}
\hline $\begin{array}{l}\text { Independent } \\
\text { variables }\end{array}$ & $\begin{array}{c}\text { Parameter } \\
\text { estimates }\end{array}$ & $\begin{array}{c}\text { Standard } \\
\text { error }\end{array}$ & t-value & $\mathbf{p}$ \\
\hline Intercept & 1,41 & 0,548 & $2,59^{* *}$ & 0,011 \\
Compensation & 0,293 & 0,104 & $2,82^{* *}$ & 0,006 \\
Job characteristics & $-0,077$ & 0,011 & $-0,73$ & 0,470 \\
$\begin{array}{l}\text { Training \& } \\
\text { Development }\end{array}$ & 0,008 & 0,109 & 0,08 & 0,940 \\
Supervisor support & 0,205 & 0,083 & $2,47^{*}$ & 0,017 \\
Career opportunities & 0,015 & 0,103 & 1,49 & 0,139 \\
Work/life policies & 0,138 & 0,068 & $2,01^{*}$ & 0,048 \\
\hline
\end{tabular}

** $\mathrm{p}=0,01 ;{ }^{*} \mathrm{p}=0,05$

Overall model: $\mathrm{F}=8.90 ; \mathrm{p}=0,0001 ; \mathrm{R}^{2}=0,38 ;$ Adjusted $\mathrm{R}^{2}=0,34$.

In Table 4 the results of the relation between the specified independent variables and continuance commitment are presented. The results of the overall model are nonsignificant and all the retention factors explain only 11 percent of the variance in the continuance commitment variable. Job characteristics (-) is the only predictor statistically different from zero and has a direct effect on continuance commitment. Compensation $(+)$, training and development opportunities $(+)$, supervisor support $(+)$, career opportunities (-) and work/ life policies $(+)$ had no significant direct effect on continuance commitment.

TABLE 4

MULTIPLE LINEAR REGRESSION ANALYSIS OF RFMS SCORES ON OCQ CONTINUOUS COMMITMENT $(\mathrm{N}=\mathbf{9 4})$

\begin{tabular}{lcccc}
\hline $\begin{array}{l}\text { Independent } \\
\text { variables }\end{array}$ & $\begin{array}{c}\text { Parameter } \\
\text { estimates }\end{array}$ & $\begin{array}{c}\text { Standard } \\
\text { error }\end{array}$ & t-value & $\mathrm{p}$ \\
\hline Intercept & 3,480 & 0,658 & $5,29 * *$ & 0,0001 \\
Compensation & 0,013 & 0,125 & 0,11 & 0,916 \\
Job characteristics & $-0,270$ & 0,127 & $-2,12^{*}$ & 0,037 \\
$\begin{array}{l}\text { Training \& } \\
\text { Development }\end{array}$ & 0,166 & 0,131 & 1,27 & 0,208 \\
Supervisor support & 0,020 & 0,100 & 0,20 & 0,841 \\
Career opportunities & $-0,112$ & 0,123 & $-0,90$ & 0,369 \\
Work/life policies & 0,136 & 0,083 & 1,65 & 0,103 \\
\hline
\end{tabular}

** $\mathrm{p}=0,01 ;{ }^{*} \mathrm{p}=0,05$

Overall model: $\mathrm{F}=1,70 ; \mathrm{p}=0,1296 ; \mathrm{R}^{2}=0,11$; Adjusted $\mathrm{R}^{2}=0,04$,
In Table 5 the results of the relation between the specified independent variables and normative commitment are presented. The overall model is nonsignificant and all the retention factors explain only 21 percent of the variance in the normative commitment variable as indicated by $\mathrm{R}^{2}$. All the retention factors are nonsignificant except compensation $(+)$, which was statistically different from zero and had a direct effect on normative commitment. Job characteristics (-), training and development opportunities $(+)$, supervisor support $(+)$, career opportunities $(+)$ and work/life policies $(+)$ had no direct effect on normative commitment.

TABLE 5

MULTIPLE LINEAR REGRESSION ANALYSIS OF RFMS SCORES ON OCQ NORMATIVE COMMITMENT $(\mathbf{N}=94)$

\begin{tabular}{lcccc}
\hline $\begin{array}{l}\text { Independent } \\
\text { variables }\end{array}$ & $\begin{array}{c}\text { Parameter } \\
\text { estimates }\end{array}$ & $\begin{array}{c}\text { Standard } \\
\text { error }\end{array}$ & t-value & $\mathrm{p}$ \\
\hline Intercept & 1,618 & 0,637 & $2,54^{* *}$ & 0,013 \\
Compensation & 0,260 & 0,121 & $2,14^{*}$ & 0,035 \\
Job characteristics & $-0,046$ & 0,123 & $-0,37$ & 0,710 \\
$\begin{array}{l}\text { Training \& } \\
\text { Development }\end{array}$ & 0,162 & 0,127 & 1,28 & 0,205 \\
Supervisor support & 0,108 & 0,097 & 1,12 & 0,265 \\
Career opportunities & 0,047 & 0,120 & 1,39 & 0,699 \\
Work/life policies & 0,025 & 0,080 & 0,31 & 0,756 \\
\hline
\end{tabular}

* * $\mathrm{p}=0,01 ;{ }^{*} \mathrm{p}=0,05$

Overall model: $\mathrm{F}=3,74 ; \mathrm{p}=0,0023 ; \mathrm{R}^{2}=0,21 ;$ Adjusted $\mathrm{R}^{2}=0,15$,

In Table 6 the results of the relation between the specified independent variables and organisational commitment are presented. The overall model is significant at the 0.01 level and retention factors explained 30 percent of the organisational commitment variable. Compensation (+) was the only predictor statistically different from zero and had significant and direct effects on organisational commitment at the 0.05 level. Supervisor support $(+)$ and work/life policies $(+)$ had a significant effect on organisational commitment only at the 0.10 level. Job characteristics (-), training and development opportunities (+) and career opportunities $(+)$ had no significant direct effect on organisational commitment.

TABLE 6

MULTIPLE LINEAR REGRESSION ANALYSIS OF RFMS SCORES ON OCQ ORGANISATIONAL COMMITMENT $(\mathbf{N}=\mathbf{9 4})$

\begin{tabular}{lcccc}
\hline $\begin{array}{l}\text { Independent } \\
\text { variables }\end{array}$ & $\begin{array}{c}\text { Parameter } \\
\text { estimates }\end{array}$ & $\begin{array}{c}\text { Standard } \\
\text { error }\end{array}$ & t-value & $\mathbf{p}$ \\
\hline Intercept & 2,173 & 0,440 & $4,94^{* * *}$ & 0,000 \\
Compensation & 0,188 & 0,830 & $2,26^{* *}$ & 0,027 \\
Job characteristics & $-0,131$ & 0,085 & $-1,54$ & 0,126 \\
$\begin{array}{l}\text { Training \& } \\
\text { Development }\end{array}$ & 0,112 & 0,088 & 1,28 & 0,204 \\
Supervisor support & 0,111 & 0,067 & $1,67 *$ & 0,099 \\
Career opportunities & 0,030 & 0,083 & 0,36 & 0,721 \\
Work/life policies & 0,100 & 0,055 & $1,81^{*}$ & 0,074 \\
\hline
\end{tabular}

${ }^{* * *} \mathrm{p}=0,01 ;{ }^{* *} \mathrm{p}=0,05 ;{ }^{*} \mathrm{p}=0,10$

Overall model: $\mathrm{F}=6.16 ; \mathrm{p}=0,0001 ; \mathrm{R}^{2}=0,30 ;$ Adjusted $\mathrm{R}^{2}=0,25$, 


\section{DISCUSSION}

The goal of this research was to investigate specific retention factors that induce organisational commitment and can thus increase the retention of high technology employees. It was hypothesised that the various retention factors will relate significantly to the three forms of organisational commitment and therefore have a significant effect on individuals' mindsets about the organisation.

The overall fit of the various models, as indicated by the $\mathrm{R}^{2}$, indicated that a low percentage of the variation had been explained. The best results were obtained for affective commitment and the worst for continuance commitment. It appears that the high technology workers that participated in this study had a desire to stay with the current organisation most probably because they generally accepted the terms of the psychological contract which positively addressed the various retention factors.

In agreement with this observation, the most relevant explanatory factors were compensation, job characteristics, supervisor support, and work/life policies, which appeared to have a significant influence on the development of affective commitment (compensation, supervisor support, work/life policies), continuance commitment (job characteristics), normative commitment (compensation) and organisational commitment (compensation, supervisor support, work/life policies) in the participants. Although training and development and career opportunities showed a significant relation to affective, normative and organisational commitment the results indicated, contrary to the findings of Kochanski and Ledford (2001) and McElroy (2001), that these two retention factors did not have any significant direct impact on the development of organisational commitment in the participants. This finding confirms results of a study conducted by Paré et al. (2001) that found training as having little effect on particularly continuance commitment.

Generally the results showed that compensation had a strong, significant relation to organisational commitment, affective commitment and normative commitment. The results obtained in the study are supported by Higginbotham's study (1997) on pay satisfaction, and Kochanski and Ledford's study (2001) on retaining high technology professionals. The findings confirm that high technology employees want a competitive salary. Perceptions of a "fair" salary have shown to be positively linked to affective commitment (Schaubroeck et al., 1994) and with an intention to stay (Higginbotham, 1997). Because of the high technology employee's commitment to their team, group-based pay may result in more commitment to the organisation (Kochanski \& Ledford, 2001; Tomlinson, 2002).

According to the results, job characteristics had a significant strong negative relation to continuance commitment. High technology employees' work requires them to use a number of complex or high level skills. This gives them considerable opportunity for independence, skill proficiency and freedom in how they complete their work (Dubie, 2000; McEachern, 2001). Continuance commitment creates a mindset of perceived costs, which compels the employees to stay in the organisation because of sunken costs (Meyer \& Herscovitch, 2001). The majority of the participants were between the ages of 25 and 29 and with organisational tenure of fewer than 5 years, which suggest that few organisational investments had been made. These high technology employees could thus easily resign because of their high skill set demand in the market and minimal investments in the company.

The relation between supervisor support and affective commitment was strongly significant. Supervisor support provides individuals with the chance to make a difference on the job, try out new skills, exercise discretion and receive feedback on their performance (Kochanski \& Ledford, 2001). This is supported by Paré et al. (2001) who demonstrated clearly that high technology employees are particularly sensitive to recognition, which has been shown to have a direct effect on affective commitment. Supervisor support makes high technology employees feel important and responsible in that they can use their innovation and skill to the advantage of the organisation (Eisenberger et al., 1990). This is a major intrinsic motivation for individuals.

Contrary to Pare et al.'s (2001) findings, the relation between work/life policies and affective commitment was significant. It appears that the participants felt emotionally attracted to the organisation most probably because of the work/life benefits available to them. These benefits are generally seen as a general indicator of corporate concern and responsibility (Dubie, 2000; Grover \& Crooker, 1995). Many high technology organisations offer employees family responsibility leave, referral programmes, flexible work arrangements and other human resources policies aimed at helping them balance work and family responsibilities (Friedan, 1989; Leinfuss, 1998). The majority of participants were between 25 and 29 years old, and were about equally divided into single and married employees. The majority of employees worked between 1 and 19 hours' overtime per week. Basically, for people to commit to an organisation, they need to know they are cared about (Burke \& Cooper, 2002; Dubie, 2000).

High technology organisations are not just interested in retaining employees, but also creating a mutually beneficial interdependence with employees (McNee et al., 1998; Murphy, 2000). The identified retention factors might serve as a means to demonstrate the organisation's support for, or commitment to, their employees and in turn cultivate a reciprocal attachment by employees. Employees' organisational commitment is related to their belief that the identified retention factors are motivated by the desire to retain good employees and to be fair in the treatment of employees (Tsui et al., 1995).

The aim of the present study was to assist human resources professionals and researchers in identifying the effect of retention factors on high technology employees' organisational commitment. However, in future investigations several of the limitations of this study would need to be considered. Firstly, participants from various organisations in the high technology industry could be used to obtain a more representative sample. Secondly, longitudinal studies are needed in order to validate the predictive dimension of the model. Future studies could include an investigation of the retention factors' effect on the attitudinal or behavioural commitment of high technology employees. High technology employees can become more committed to their own profession, because of the respect they receive as experts and the ability to deal with difficult technical situations. A study could investigate the difference in retention factors on their professional commitment and organisational commitment. As the workforce is becoming more diverse, a study could investigate the effect of retention factors on organisational commitment in a nonhomogenous employee environment. Finally, as individuals are increasingly unable to depend on a single organisation for their entire career because of mergers, downsizing and layoffs, a longitudinal study could investigate the employee emigration from organisational commitment to career commitment.

In conclusion, it is trusted that these findings presented useful insights regarding the retention of valuable high technology employees. Researchers are encouraged to examine, both theoretically and empirically, these and other retention and commitment constructs to yield more insightful conclusions regarding the effect of retention factors on employees' organisational commitment. 


\section{REFERENCES}

Agarwal, R. \& Ferratt, T. W. (1999). Coping with labour scarcity in IT: Strategies and practices for effective recruitment and retention. Cincinnati, $\mathrm{OH}$ : Pinnaflex.

Allen, N. J. \& Meyer, J. P. (1990). The measurement and antecedents of affective, continuance and normative commitment to the organisation. Journal of Occupational Psychology, 63, 1-18.

Allen, N. J. \& Meyer, J. P. (1993). Organisational commitment: Evidence of career stage effects? Journal of Business Research, 26, 49-61.

Amabile, T. M., Conti, R., Coon, H., Lazenby, J., \& Herron, M. (1996). Assessing the work environment for creativity. Academy of Management Journal, 39, 1154-1184.

Balkin, D. B. \& Gomez-Mejia, L. R. (1984). Faculty satisfaction with pay and other job dimensions under union and nonunion conditions. Academy of Management Journal, 27 (3), $591-602$.

Baruch, Y. (2004). Transforming careers: From linear to multidirectional career paths. Career Development International, 9 (1), 58-73.

Baugh, S. G. \& Roberts, R. M. (1994). Professional and organisational commitment among engineers: Conflicting or complementing? IEEE Transactions on Engineering Management, 41, 108-114.

Becker, H. S. (1960). Notes on the concept of commitment. American Journal of Sociology, 66, 32-42.

Burke, R.J. \& Cooper, C.L. (2002). The new world of work: Challenges and opportunities. Oxford: Blackwell.

Cascio, W. F. (2003). Managing human resources. New York: McGraw-Hill.

Cataldo, P., van Assen, J. \& D'Alessandro, A. (2000). How to win the telecom talent war: Companies can retain a best-in-class workforce in a highly competitive labour market using a knowledge-based approach that emphasises continuous learning. America's Network, 104 (11), 55.

Chambers, E. G. (1998). Win the war for top talent. Workforce, 77 (12), 50-56.

Chang, E. (1999). Career commitment as a complex moderator of organisational commitment and turnover intention. Human Relations, 52 (10), 1257-1278.

Clark, L. A. \& Watson, D. (1995). Constructing validity: Basic issues in objective scale development. Psychological Assessment, 7, 309-319.

Cohen, A. (1993). On the discriminant validity of the Meyer and Allen (1984) measure of organisational commitment: how does it fir with the work commitment construct? Organisational Behaviour, 14, 82-91.

DeCotiis, T. A. \& Summers, T. P. (1987). A path analysis of a model of the antecedents and consequences of organisational commitment. Human Relations, 40, 445-470.

DeYoung, P. (2000). High technical talent perks are ripe for the picking. Workspan, 43 (10), 28-33.

Döckel, A. (2003). The effect of retention factors on organisational commitment: An investigation of high technology employees. Unpublished MCom dissertation (Human Resources Management), University of Pretoria.

Dubie, D. (2000). Should you stay or should you go? Network World, 17 (29), 66.

Eisenberger, R., Fasolo, P. \& Davis-LaMastro, V. (1990). Perceived organisational support and employee diligence, commitment, and innovation. Journal of Applied Psychology, $75,51-59$.

Eisenhardt, K. M. (1985). Control: organisational and economic approaches. Management Science, 31, 134-149.

Evans, R. S., Gonzalez, J., Popiel, S. \& Walker, T. (2000). Whose capital is it? Trends in human resources. Ivey Business Journal, 64 (3), 28-37.

Farris, G. F. (2000). Rewards and retention of technical staff. IEEE International Engineering Management Conference, 617-619.
Fried, Y. \& Farris, G. R. (1987). The validity of the job characteristic model: A review and meta-analyses. Personnel Psychology, 4 (2), 287-322.

Friedan, B. (1989). Mommy track [Videotape recording of ABC's News Nightline]. New York: ABC News.

Furnham, A. (2000). Work in 2020: Prognostications about the world of work 20 years into the millennium. Journal of Managerial Psychology, 15 (3), 242-254.

Glynn, M. A. (1996). Innovative genius: A framework for relating individual and organisational intelligences to innovation. Academy of Management Journal, 21 (4), 1081-1111.

Grover, S. L. \& Crooker, K. J. (1995). Who appreciates familyresponsive human resources policies: The impact of familyfriendly policies on the organisational attachment of parent and non-parents. Personnel Psychology, 48 (2), 271-289.

Hackman, J. R. \& Oldham, G. R. (1975). The development of the Job Diagnostic Survey. Journal of Applied Psychology, 60, 159-170.

Hackman, J. R. \& Oldham, G. R. (1976). Motivation through the design of work: Tests of a theory. Organisational Behaviour and Human Performance, 16, 250-279.

Heneman, H. G. III \& Schwab, D. P. (1985). Pay satisfaction: Its multidimensional nature and measurement. International Journal of Psychology, 20, 129-141.

Higginbotham, J. S. (1997). The satisfaction equation. Research \& Development, 39 (10), 1-9.

Hoyt, J. \& Gerdloff, E. A. (1999). Organisational environment, changing economic conditions and the effective supervision of technical personnel: a management challenge. Journal of High Technology Management Research, 10 (2), 275-294.

Huselid, M. A. (1995). The impact of human resource management practices on turnover, productivity, and corporate financial performance. Academy of Management Journal, 38, 635-672.

Igbaria, M. \& Greenhaus, J. (1992). Determinants of MIS employees' turnover intentions: A structural equation model. Communications of the ACM, 35 (2), 34-49.

Jiang, J. J. \& Klein, G. (2000). Supervisor support and career anchor on the career satisfaction of the entry-level information systems professional. Journal of Management Information Systems, 16 (3), 219-240.

Kochanski, J. \& Ledford, G. (2001). "How to keep me": Retaining technical professionals. Research Technology Management, 44 (3), 31-38.

Landau, J. \& Hammer, T. H. (1986). Clerical employees' perceptions of intraorganisational career opportunities. Academy of Management Journal, 29 (2), 385-404.

Leinfuss, E. (1998). The hiring frenzy continues. Computerworld, $32(27), 64-65$

Luthans, F., McCaul, H. S. Dodd, N. G. (1985). Organisational communications: A comparison of America, Japanese and Korean employees. Academy of Management Journal, 28 (1), 213-219.

Marsh, R. M. \& Mannari, H. (1977). Organisational commitment and turnover: a predictive study. Administrative Science Quarterly, 22, 57-75.

Mathieu, J. E. \& Farr, J. L. (1991). Further evidence for the discriminant validity of measures of organisational commitment, job involvement and job satisfaction. Journal of Applied Psychology, 76, 127-133.

Mathieu J. E. \& Zajac, D. (1990). A review and meta analysis of the antecedents, correlates and consequences of organisational commitment. Psychological Bulletin, 108 171-194.

McCrory, A. (1999). Workstyles. Computerworld, January 25, $65-66$.

McEachern, C. (2001). The economy may be slowing, but retaining a quality technical department is always key. Wall Street \& Technology, 19 (7), 43-46.

McElroy, J. C. (2001). Managing workplace commitment by putting people first. Human Resources Management Review, $11,327-335$. 
McNee, B., Morello, T., Zidar, E. \& Smith, C. (1998). Strategic human resources management: Addressing a critical problem for the information systems organisation. Gartner Group Strategic Analysis Report, September 28.

Mester, C., Visser, D., Roodt, G. \& Kellerman, R. (2003). Leadership style and its relation to employee attitudes and behaviour. SA Journal of Industrial Psychology, 29 (2), 72-82.

Meyer, J. P. \& Allen, N. J. (1984). Testing the "side bet theory" of organisational commitment: Some methodological considerations. Journal of Applied Psychology, 69, 372-378.

Meyer, J. P. \& Allen, N. J. (1991). A three component conceptualisation of organisational commitment. Human Resources Management Review, 1, 61-89.

Meyer, J. P. \& Allen, N. J. (1997). Commitment in the workplace: Theory, research and application. Thousand Oaks, CA: Sage.

Meyer, J. P., Allen, N. J. \& Smith, C. A. (1993). Commitment to organisations and occupations: Extension and test of three component conceptualisation. Journal of Applied Psychology, 78, 538-551.

Meyer, J. P. \& Herscovitch, L. (2001). Commitment in the workplace: Toward a general model. Human Resources Management Review, 11, 299-326.

Miner, J. B. (1988). Organisational behaviour: Performance and Productivity. New York: Random House.

Morrow, P. C. \& McElroy, J. C. (1986). On assessing measures of work commitment. Journal of Occupational Behaviour, 7, 139-145.

Mueller, C. W., Wallace, J. E. \& Price, J. L. (1992). Employee commitment: Resolving some issues. Work and Occupations, 19, 211-236.

Murphy, C. (2000). The survey says: Lots of IT jobs, not enough workers. Information Week, No 782, 152.

Paré, G., Tremblay, M. \& Lalonde, P. (2001). The role of organisational commitment and citizenship behaviours in understanding relations between human resources practices and turnover intentions of IT personnel. Scientific Series \#2001s-24, CIRANO, Montreal, Canada.

Pretorius,A.A.S. \& Roodt, G. (2004). Die verband tussen werknemertevredenheid en organisasieverbondenheid. $S A$ Journal of Industrial Psychology, 30 (3), 65-74.

Ramus, C. A. \& Steger, U. (2000). The roles of supervisory support behaviours and environmental policy in employees "ecoinitiatives" at leading edge European companies. Academy of Management Journal, 43 (4), 605-626.

Rhodes, S. R. \& Steers, R. M. (1981). Conventional versus workerowned firms. Human Relations, 34, 1013-1035.

Rogers, E. W. (2001). A theoretical look at firm performance in high technology organisations: What does existing theory tell us? Journal of High Technology Management Research, 12, $39-61$.
Rogg, K. L., Schmidt, D. B., Shull, C. \& Schmitt, N. (2001). Human resources practices, organisational climate and customer satisfaction. Journal of Management, $27,431-449$.

SAS Institute. (2000). The SAS System for Windows: Release 8.01. Cary: SAS Institute Inc.

Schaubroeck, J., May, D. R. \& Brown, F. W. (1994). Procedural justice explanations and employee reactions to economic hardship: A field experiment. Journal of Applied Psychology, $79,455-460$.

Shaughnessy, J.J. \& Zechmeister, E.B. (1997). Research methods in psychology. New York: McGraw-Hill.

Scholl, R. W. (1981). Differentiating commitment from expectancy as motivating force. Academy of Management Review, 6, 589-599.

Sethi, V., Meinert, D., King, R. C. \& Sethi, V. (1996). The multidimensional nature of organisational commitment among information systems personnel. Available online at http://hsb.baylor.edu/ramsower/ais.ac.96/papers/sethi.htm. (Accessed 03/10/2001).

Storey, J. (1992). Developments in the management of human resources. Oxford: Blackwell.

Storm, L. \& Roodt, G. (2002). Die verband tussen organisasiesosialisering en organisasieverbondenheid. Tydskrif vir Bedryfsielkunde, 28 (1), 14-21.

Terre Blanche, M. \& Durrheim, K. (1999). Research in practice: Applied methods for the social sciences. Cape Town: University of Cape Town Press.

Tomlinson, A. (2002). High technology workers want respect: Survey. Canadian Human Resources Reporter, 15 (3), 2.

Tredoux, C. \& Durrheim, K. (2002). Numbers, hypotheses \& conclusions: A course in statistics for the social sciences. Cape Town: UCT Press.

Tsui, A. S., Pearce, J. L., Porter, L. W. \& Hite, J. P. (1995). Choice of employee-organisation relationship: Influence of external and internal organisational factors, in G. R. Ferris (ed.) Research in personnel and human resources management (pp. 117-151). Greenwich, CT: JAI.

Turbin, M. S. \& Rosse, J. G. (1990). Staffing issues in the high technology industry, in L. R. Gomez-Meijia \& M. W. Lawless (eds.). Organisation issues in high technology management. London: JAI.

Von Glinow, M. A. \& Mohrman, S. A. (1990). Attachment and withdrawal patterns of high technology workers. Journal of High Technology Management Research, 1 (2), 149-165.

Weiss, J.W. (2001). Organizational behaviour and change: Managing diversity, cross-cultural dynamics, and ethics. Ohio: South-Western College.

Wiener, Y. (1982). Commitment in organisations: a normative view. Academy of Management Review, 7, 418-428. 